is now named and described as new, the name being derived from the peculiar form of its corona, concerning which I have already spoken at some length. In general appearance it closely resembles C. Trifolii and C. Epithymum.

4. C. europaa (Linn.); florum glomerulis bracteatis sessilibus, tubo corollæ per anthesin cylindrico, fructiferæ ventricoso, squamis adpressis erectis bifidis basi distantibus : lobis divergentibus attenuatis, calyce corolla multo breviori, stigmatibus filiformibus. Pl. IV. fig. 4 . C. europæa, Linn. Sp. Pl. p. 180. excl. var. $\beta$.

Scales closely adpressed to the tube of the corolla, always present, narrow, bifid; their lobes slender, very acute, entire, or with two or three obscure teeth at the end; each scale separated from its neighbour by a broad rounded space. Stigmas filiform.

Parasitical upon herbaceous plants, such as Urtica, Humulus, Carduus, \&c.

St. John's College, Cambridge, Feb. 1, 1844.

XXXII.-Catalogue of Irish Entozoa, with observations. By O'Bryen Bellingham, M.D., Fellow of and Professor of Botany to the Royal College of Surgeons in Ireland, Member of the Royal Zoological, Geological and Natural History Societies of Dublin, \&c.

[Continued from p. 174.]

\title{
Order 2. ACANTHOCEPHALA.
}

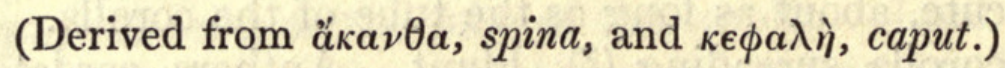

THE order Acanthocephala contains only a single genus, Echinorhynchus.

The characters of the order are as follows:-

The body is cylindrical or bladder-like, subelastic, obtuse at both extremities, provided with a retractile proboscis, which is armed with minute recurved spines arranged in a regular series. The intestinal canal is complete; the sexes are distinct ; females oviparous.

The species are numerous, and occur in all the classes of vertebral animals; they are frequently found attached to the mucous membrane of the alimentary canal by means of their proboscis, consequently their powers of locomotion must be very limited.

Genus 9. Есhinorhynchus.

(Derived from éXivos, echinus, and póvyos, proboscis.)

This is the only genus in the order; it was named by Müller, 
and the term has been adopted by all zoologists since. The species inhabit principally the alimentary canal; they are most numerous in birds and fish, less common in mammalia, and still more rare in reptiles.

Two divisions have been made of the genus : in one the neck and body are unarmed; in the other this part is provided with spines; the species are further subdivided according to the shape of the proboscis, and to the absence or presence of a neck.

Collo corporeque inermibus; proboscide cylindrica vel lineari.

1. Echinorhynchus angustatus $*\left\{\begin{array}{l}\text { Stomach and intestine of perch } \\ \text { (Perca fluviatilis). } \\ \text { Intestine of eel (Anguilla acutiros- } \\ \text { tris). } \\ \text { Intestine of trout (Salmo Fario). } \\ \text { Intestine of rudd (Cyprinus Ery- } \\ \text { throphthalmus). } \\ \text { Intestine of gudgeon (Cyprinus Go- } \\ \text { bio). } \\ \text { Intestineo three-spined stickleback } \\ \quad \text { (Gasterosteus aculeatus). } \\ \text { Intestines of pike (Esox Lucius). }\end{array}\right.$

* The Echinorhynchus angustatus is common in the perch ; the colour of this species is reddish yellow or white; the longest specimen I possess measures $4 \frac{1}{2}$ lines, including the proboscis ; the body is nearly cylindrical, a little wider anteriorly however than posteriorly; the proboscis is cylindrical, about two-thirds of a line in length; the neck is short, seldom protruded fully, and nearly of the same diameter as the proboscis; the caudal pouch in the male is large : little difference in size exists between the male and the female; the male however is much rarer than the female.

This species may be preserved in fresh water for a sufficient length of time to observe the manner in which the proboscis is protruded and retracted; as far as I have seen, the only mode in which this organ is retracted is by inversion upon itself, that surface which had been exterior when it was protruded becoming internal when it was retracted; the proboscis was always retracted slowly, and generally protruded with great rapidity.

The figure given by Müller of this species in his ' Zoologia Danica' under the name Echinorhynchus Lucii, and that which Rudolphi has given in his 'Entozoor. Hist. Nat.' under the name Echin. affinis, are not good; the proboscis is not at all so thick in proportion to the body as they have represented it to be.

The specimens of Echinorhynchus angustatus which I have found in the eel and trout are perfectly white; the longest measures nearly six lines exclusive of the proboscis; the body has a greater diameter 


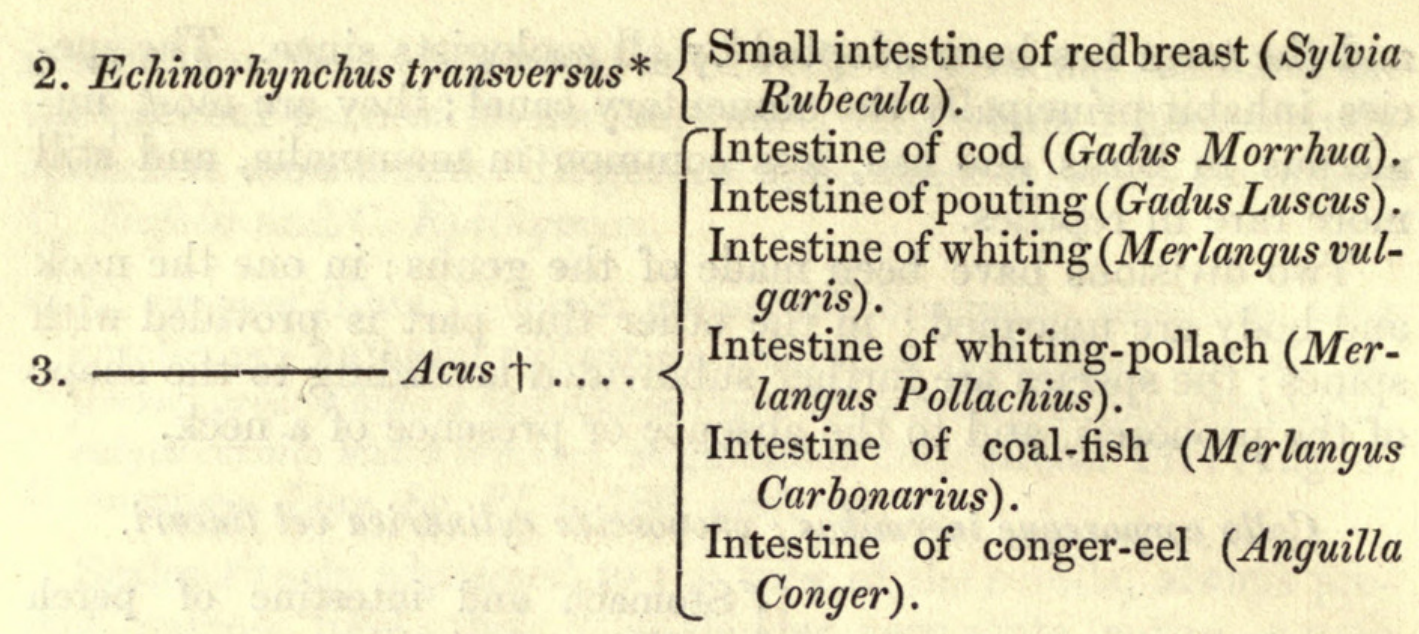

anteriorly than posteriorly ; in some (from the intestine of the eel) this is so much the case that they might be mistaken for the Echin. globulosus, if the size and shape of the proboscis did not distinguish them.

The specimens of this species which occurred in the rudd and stickleback are more equally attenuated at each extremity than those which I found in the perch and eel; and the Echin. angustatus, which inhabits the intestine of the gudgeon, resembles in every particular that which occurred in the perch.

* The colour of the Echinorhynchus transversus is a dirty white; the body is nearly cylindrical, three lines in length, a little thicker anteriorly than posteriorly ; the proboscis is linear, cylindrical, threefourths of a line in length, armed with numerous rows of recurved hooks, and is placed obliquely or transversely on the body; the posterior extremity of the body of the female is obtuse; in the male it terminates in a large globular pouch, which has a whiter colour than the other parts of the body.

† I have little to add to the excellent description of the Echinorhynchus Acus which has been given by my friend Dr. Drummond (so long the distinguished President of the Belfast Natural History Society) in the 'Magazine of Nat. History.' I have met with this species more frequently in the whiting-pollach than in any other fish, and they are more common in young cod than in the full-grown animal. When first removed from the intestine they are thick, rugose, and of a yellowish colour; after remaining for a short time in fresh water they become white, straight and turgid; the body is thicker anteriorly than posteriorly; at the posterior extremity is a minute yellowish spot; the proboscis is cylindrical and comes off obliquely; there is no neck. After remaining in fresh water for a time, some specimens ruptured near the head and an immense number of ova were discharged; these have an elliptical shape, the parietes transparent ; within each is the outline of another body nearly of the same shape, but prolonged more at the extremities, and with some dark spots in the centre. 
LONGICOLLES.
(5mall intestine of wild duck (Anas Boschas).
4. Echinorhynchus filicollis $* .\left\{\begin{array}{c}\text { Small intestine of tufted duck (Fu- } \\ \text { ligula cristata). }\end{array}\right.$
Intestine of golden eye (Clangula chrysophthalmos), by Dr. Drum- mond.
5 . tereticollis $\uparrow$ Intestine of trout (Salmo Fario). 6. nodulosus $? \neq\left\{\begin{array}{l}\text { Intestine of gillaroo trout (Salmo } \\ \text { Fario, var. }) \text {. } \\ \text { Intestines of pike (Esox Lucius }) .\end{array}\right.$

* The Echinorhynchus filicollis has been so accurately figured and described in the 'Magazine of Nat. History' for 1839 by my friend Dr. Drummond, that I have been anticipated in almost everything respecting it. Dr. Drummond has detected this species in the intestine of the golden eye and tufted duck; I have met with it in the wild duck and tufted duck.

The body of this remarkable species lies in the mucous surface of the intestine; the head projects upon the peritonæal surface but covered by peritonæum, and the neck, which is fine and strong, is contained in the substance of the walls of the intestinal canal; in the centre of the anterior surface of the head is a small conical papillary body destitute of spines; the ova (of which they contained a great number) have an oval shape and are visible to the naked eye.

+ I found a single specimen of the Echin. tereticollis in the intestine of a common river trout (Salmo Fario) in the month of October 1838; the body lay in the mucous surface of the intestine; the neck was contained in its walls (as is the case with the Echin. filicollis), and the proboscis and receptacle projected upon the peritonæal surface, but covered by a layer of peritonæum; the body is three-quarters of an inch long, about the same diameter anteriorly as posteriorly; colour white; the proboscis is linear and cylindrical, densely armed with minute spines; the neck is conical, widest next the body, transversely striated, and terminates in a globose receptacle, which is flattened anteriorly and posteriorly.

$\ddagger$ In the intestine of a gillaroo trout and of a pike I found several specimens of an Echinorhynchus which resemble the Echin. nodulosus and Echin. ovatus of Rudolphi, but differ in some respects from both. They belong to the same division, 'Longicolles;' the longest measures five lines, the smallest somewhat less; the neck and part of the body near it were of a light orange colour when removed from the intestine; the body is cylindrical, but wider anteriorly than posteriorly, and resembles in shape the body of the Echin. nodulosus; the proboscis is cylindrical, in some specimens very slightly thicker in the centre than at either extremity; the neck is cylindrical, double the thickness of the proboscis, longer than it, and marked with transverse rugæ; between the proboscis and neck is the receptacle Ann. \& Mag. N. Hist. Vol. xiii. 
Collo vel corpore armato.

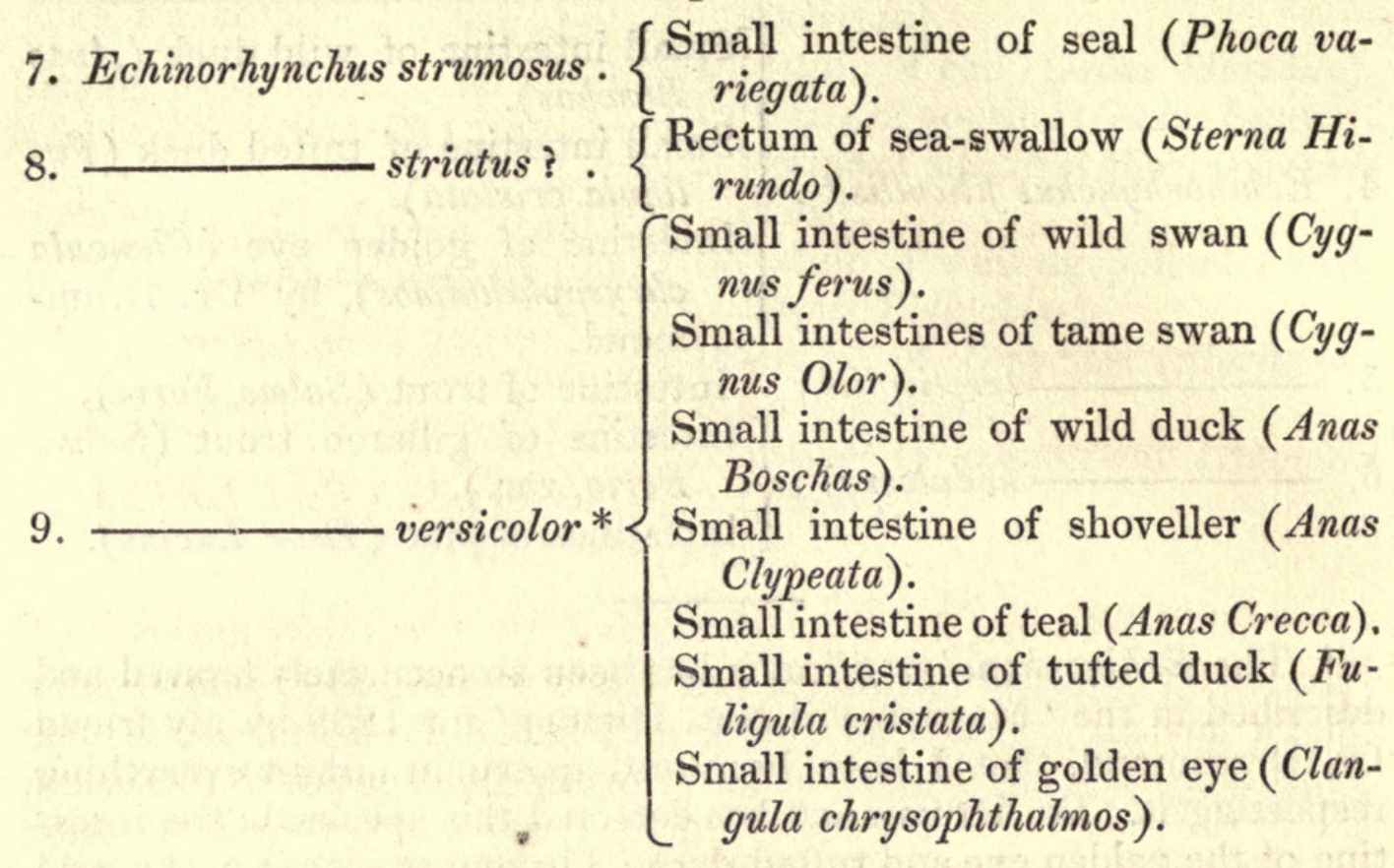

or head, which is subglobose, but not at all so large as it is in the Echin. nodulosus; the head, proboscis and neck together measure a line and a half in length. All the specimens I have met with were free in the intestine; none of them attached to its coats.

* The Echinorhynchus versicolor I have found in very large numbers in the small intestine of the tame swan; the majority were firmly attached to the mucous membrane; some had a reddish colour, others were white, but all became white after lying in spirits of wine for a certain time: the longest females measured $5 \frac{1}{2}$ lines, the males little more than 3 lines; in the largest specimens the body is constricted in two places, this is not so remarkable in the smaller specimens; the proboscis is short; the neck long, conical and unarmed; the body is somewhat thicker in front, and is armed over its whole surface, but particularly anteriorly, with numerous short spines. The body in the female terminates obtusely, in the male in a distinct pouch. The young differ in shape from the larger; in some the body has a greater diameter posteriorly than anteriorly, and is constricted in only one place.

I have met with the Echinorhynchus versicolor in the small intestine of the common wild duck, along with the Echinorhynchus filicollis; some had a reddish colour, others were white. The anterior part of the body in all is armed with innumerable very minute spines. The neck is longer than the proboscis, a little wider at the base; the vagina, from which it projects, is very distinct.

I have found this species also, but sparingly, in the small intestine near the large, and in the large intestine of the teal; they are from a line to two lines in length; the neck is long, conical and naked; the body narrower posteriorly, constricted in some about the centre, and armed anteriorly with very minute spines; the caudal extremity obtuse in the female, terminating in a small pouch in the male. 


\author{
Rectum of cormorant (Phalacroco- \\ rax $\mathrm{Carbo).}$ \\ Small and large intestine of crested \\ cormorant (Phalacrocorax crista- \\ tus). \\ 10. Echinorhynchus Hystrix $*\{$ Small intestine of red-breasted mer- \\ ganser (Mergus Serrator). \\ Rectum of red-necked grebe (Podi- \\ ceps rubricollis). \\ Rectum of goosander (Mergus Mer- \\ ganser), by Dr. Drummond.
}

In the month of March 1839, I met with this species in immense numbers in the small intestine of the golden eye, the majority firmly attached to the mucous membrane; the longest were about three lines in length, independent of the neck and proboscis ; the greater number however measured little more than a line. All were constricted in one part of the body, and in some the anterior, in others the posterior division was the larger ; the posterior portion in the great majority had a beautiful red colour, which faded after lying in water or spirits of wine ; the anterior white, pellucid, and armed over nearly its whole surface, but particularly anteriorly, with very minute recurved spines : the anterior division of the body has the greater diameter when the proboscis and neck are retracted; when fully protruded however, this part is more slender than the posterior. The proboscis is short and armed with prominent spines; in many the neck is hardly visible: the caudal pouch in the male is separated from the body by a narrower portion.

* In the month of May $1838 \mathrm{I}$ found a considerable number of the Echinorhynchus Hystrix in the large and small intestine of the crested cormorant, the majority firmly attached to the mucous membrane; the greater number and the largest existed in the rectum and close to its short cæca; in the small intestine they were fewer in number and less in size. Their colour white; the longest three lines in length, and a line in diameter at the thickest part of the body; the males not so large as the females; the proboscis conical, armed with very numerous recurved spines; the neck retracted in some; when fully protruded it is about the length of the head, smaller where it joins the head, and increasing in diameter posteriorly ; it is unarmed. The body is somewhat globular anteriorly, gradually diminishing in diameter as it approaches the posterior extremity; it is armed, especially anteriorly, with innumerable minute recurved spines: some specimens are armed from one extremity of the body to the other, others are unarmed near the posterior extremity: the body of the female is rounded posteriorly, and a very small yellowish spot is visible at its extremity.

Two vessels or canals are seen through the parietes of the neck running into the body, where they are lost. This species has been very accurately described by my friend Dr. Drummond in the 'Ma- 
Species dubia.

11. Echinorhynchus. Rectum of plover (Charadrius Hiaticula).

12.

Small intestine of water-ouzel (Cinclus aquaticus).

13. - Small intestine of smew (Mergus albellus).

14. Small intestine of king-eider (Somateria spectabilis).

15.

Small intestines of rabbit (Lepus Cuniculus).

gazine of Natural History ;' it does not appear to have been ever found by Rudolphi, who has given a description of the species from some specimens communicated to him by Bremser. Bremser found it in but one species, the common cormorant ; I have met with it, in addition to the common cormorant, in the crested cormorant, the redbreasted merganser, and in the red-necked grebe, and Dr. Drummond has found it in the goosander.

[To be continued.]

XXXIII.-A List of Lichens gathered in different parts of Wales, principally in the neighbourhood of Barmouth, with a few casual observations upon some of the species. By the Rev. T. SALwey.

\section{To Richard Taylor, Esq.}

\section{Dear Sir,}

Oswestry, Feb. 10, 1844.

MAY I request that you will have the kindness to allow me a page or two of your valuable Magazine to supply a few omissions in my list of Welsh Lichens inserted in your January Number? I am, dear Sir, yours faithfully, T. Salwey.

1. Variolaria multipunctata. On trees in the woods about Tyn-yGooes, \&c.

2. Endocarpon Hedwigii, $\beta$ lachneum *. In patches about the rocks; at the angle of the turnpike-road turning down to the harbour between Borthwen and Barmouth, sparingly.

3. — rufo-virescens, Taylor. On the high wall of the turnpike-road on the right-hand side leading from Barmouth to Harlech, just by the first mile-stone.

This grows not uncommonly upon the walls near Barmouth. It

* Acharius well observes in his 'Syn.' on this species, that both the colour and the figure of the thallus greatly vary, so that it is not to be wondered at that several species have been made out of one. My specimens are of a reddish brown colour and without apothecia. Those which I have received from other quarters, as "lachreum," are of a paler colour, and with numerous apothecia. I think the "lachneum" of Fl. Hib. "growing upon rocks in mountain streams" must be a distinct species, as Taylor has made it. 


\section{$2 \mathrm{BHL}$ Biodiversity Heritage Library}

Bellingham, O'Bryen. 1844. "XXXII.-Catalogue of Irish Entozoa, with observations." The Annals and magazine of natural history; zoology, botany, and geology 13, 254-260. https://doi.org/10.1080/03745484409442603.

View This Item Online: https://www.biodiversitylibrary.org/item/19482

DOI: https://doi.org/10.1080/03745484409442603

Permalink: https://www.biodiversitylibrary.org/partpdf/3686

\section{Holding Institution}

Natural History Museum Library, London

\section{Sponsored by}

Natural History Museum Library, London

\section{Copyright \& Reuse}

Copyright Status: Public domain. The BHL considers that this work is no longer under copyright protection.

This document was created from content at the Biodiversity Heritage Library, the world's largest open access digital library for biodiversity literature and archives. Visit BHL at https://www.biodiversitylibrary.org. 